\title{
Protein Patterns of Silkworm Bombyx mori L. Fed on Leaves of Wild and Cultivated Mulberry Varieties
}

\author{
Kariman M. Mahmoud \\ Plant Protection Department, Faculty of Agriculture, Suez Canal University, Ismailia, Egypt.
}

Received: $5 / 3 / 2017$

\begin{abstract}
Sodium dodecyl sulphate polyacrylamide gradient gel electrophoresis (SDS-PAGE) was used to determine the protein profiles of two mulberry variety leaves: the cultivated Morus alba var. Morittiana and the wild one Morus laevigata and their effects on haemolymph and silkgland protein patterns in final larval instar of silkworm Bombyx mori L. Results showed some differences in the number and abundance of protein bands in the two studied mulberry variety leaves as they were 5 bands in Morus alba var. Morittiana ranged between (47.27- 344.47 kDa), while, were 10 bands in Morus laevigata leaves ranged between (17.79- 350.11 kDa). However there were close similarity in haemolymph and silkgland protein patterns of larvae fed on the both studied mulberry varieties, which registrad 12 protein band in haemolymph and 15 protein bands in silkgland of larvae fed on the two mulberry varities.
\end{abstract}

Keywords: Bombyx mori, mulberry varieties, haemolymph protein patterns, silkgland protein patterns.

\section{INTRODUCTION}

Proteins are the building blocks of organisms therefore, proteins are important in all biological systems and play a wide variety of structural and functional roles. Proteins are also compounds of fundamental importance for all functions in the cell. The protein budget of the cell can be considered as an important analyte in evaluating the physiological standards of the cell. The high protein concentration is an indication of a greater metabolic activity of the tissue. So improvement of the food value is probably determined by the protein quantity and quality (Li et al., 2012; Rajitha and Savithri, 2013; Madhu Babu et al., 2014).

Mulberry has an economic importance in silk industry due to its foliage, which constitutes the chief food for the silkworm, Bombyx mori L. Because of its richness with protein the nutritive value of the mulberry leaves have a considerable influence on the growth of the silkworm. In addition, other components of the leaves are helping the silkworm to meet its dietary requirements. Nearly 70 percent of the silk produced by silkworm is directly derived from proteins of mulberry leaves (Machii and Katagiri, 1991).

Most methods used to evaluate the leaf quality or variations between different varieties are biochemical methods, phytochemical analysis or nutritive contents of different mulberry genotypes (Jyothi et al., 2014; Manjula and Kumari, 2015). On the other hand the performance of the Bombyx mori is based on economic, biological characters and productivity. These assessments have been conducted to assess the effect of different mulberry cultivars on silkworm rearing (Babu et al., 2014; Prieto-Abreu et al., 2016). However other studies on the biochemical components and bioassay of different varieties of mulberry leaves fed by silkworm in relation to silk production were done by Zannoon et al. (2008).

Recent studies concerned with the protein quantification by SDS-PAGE gel electrophoresis were carried out to demonstrate the variability in protein profiles between different mulberry cultivars only
(Madhu Babu et al., 2014; Jyothi et al., 2016), on the other hand, the comparative proteomic maps approach was applied to assess many factors that affect the silkworm haemolymph and posterior silkgland protein patterns (Li et al., 2012; Zhang et al., 2014; Dong et al., 2016). Meanwhile the effect of cultivated mulberry varieties on haemolymph protein patterns was investigated by El-Akkad et al. (2008). On other hand no study was carried out to find the relation and effects of the protein patterns of different mulberry varieties on silkworm larvae protein patterns.

The present study was carried out to compare the protein profile of leaves of cultivated and wild mulberry varieties, and their effect on silkworm haemolymph and silkgland proteins patterns. Results can be used to assess as index in silkworm feeding program.

\section{MATERIALS AND METHODS}

\section{Experimental silkworm rearing}

The experiment was conducted at the Plant Protection Department, Faculty of Agriculture, Suez Canal University Ismailia, Egypt. Experimental silkworm eggs of four-way hybrid $(\mathrm{KK} \times$ Hesa 1$) \times$ (Vesletz $2 \times$ Gergana 2), was imported from Sericulture and Agriculture Experiment Station, Vratza, Bulgaria.

Larvae were reared in plastic containers placed in a chamber where the temperature was at $25 \pm 1{ }^{\circ} \mathrm{C}$ and the relative humidity was $75 \pm 5 \%$, fed on fresh mulberry leaves from hatching to the fifth instar four times per day. Leaves were collected from healthy plants at Faculty of Agriculture Farm. Two groups of mulberry variety were used, namely the cultivated mulberry variety Morus alba L. var. Morittiana and the wild one, Morus laevigata which was grafted on Morus alba L. var. Morittiana branches each group divided to 3 replicates.

\section{Electrophoretic analysis of proteins (SDS-PAGE) \\ Mulberry leaves preparation and proteins analysis}

Healthy leaves were collected from medium portions of mulberry plants as pooled samples with three replicates of each variety. $1 \mathrm{gm}$ of leaf samples were weighed and homogenized with $5 \mathrm{ml}$ of extraction 
buffer. The samples were centrifuged at $10,000 \mathrm{rpm}$ for 20 minutes. The supernatants of were collected and used for the electrophoresis protein profile estimation.

Samples were mixed with loading the buffer and heated at $95^{\circ} \mathrm{C}$ for $5-10$ minutes. The sandwich was clipped to the electrophoresis apparatus filled with Trisglycine-SDS Buffer in the lower chamber. $100 \mu \mathrm{g}$ of each sample was loaded into the bottom of the walls using micropipette fitted with long tip. The apparatus was connected to the power supply started electrophoresis process at $50 \mathrm{~V}$ for the first $30 \mathrm{~min}$ and then increased the voltage to $100 \mathrm{~V}$. The gel was transferred in Coommassie blue staining solution and incubated overnight, then transferred to a distaining solution $(200 \mathrm{ml}$ methanol, $50 \mathrm{ml}$ acetic acid and $750 \mathrm{ml}$ distilled water) and left for several hours until the protein bands appeared (Jyothi et al., 2016).

\section{Haemolymph and silkgland proteins preparation and analysis}

According to Bovilla et al. (2016), the maximum protein concentration was observed on the $7^{\text {th }}$ day of the fifth larval instar. Therefore, haemolymph of ten $5^{\text {th }}$ instar larvae (7-day old) from each replicate were collected by cutting caudal horn and stored at $-80^{\circ} \mathrm{C}$ for further use. Subsequently, posterior silkglands were collected from the same larvae, homogenized in $0.01 \mathrm{M}$ Tris- $\mathrm{HCl}(\mathrm{pH} 8.8)$ buffer. The homogenates were filtered and the filtrates were centrifuged for $10 \mathrm{~min}$. The supernatant was collected and washed in $0.75 \%$ icecold physiological salt solution, blotted on a filter paper, allowed to freeze in liquid nitrogen immediately, and stored at $-80^{\circ} \mathrm{C}$ for further use.

One-dimensional sodium dodecyl sulfatepolyacrylamide electrophoresis (1D SDS-PAGE) were carried out according to (Zhou et al., 2008; Li et al., 2009) for haemolymph protein analysis, while the procedure established by Vasudha et al. (2006) was used for silkgland proteins electrophoresis analysis.

The electrophoresed 1D gels were visualized by Coomassie Brilliant Blue R250 (CBB-R250, Sigma, St. Louis, MO, USA). Densitometric analysis Gels were analyzed comparing the banding patterns abundance (raw volume percentage) and their molecular mass against protein molecular markers run parallel along with samples using gel image analysis softwareSynGene Gene Tools - File version: 4.03.05.0 installed and photographed in gel documentation unit in the Institute of Biotechnology for Post Graduate and Research at Suez Canal University.

\section{RESULTS}

\section{Electrophoretic patterns of mulberry leaves proteins}

The qualitative analysis of separated protein bands from the M. alba var. Morittiana and M. laevigata leaves was done by SDS-PAGE. Electrophoresis analysis separated only 5 bands in $M$. alba var.
Morittiana leaves while in $M$. laevigata leaves, 10 protein bands were separated with molecular weight ranged from $17.79 \mathrm{kDa}$ to $345 \mathrm{kDa}$ (Table 1 and Figure 1). Protein bands with molecular weight of $345.11 \mathrm{kDa}$, $100.00 \mathrm{kDa}, 87.40 \mathrm{kDa}, 74.16 \mathrm{kDa}, 67.74 \mathrm{kDa}, 57.36$ $\mathrm{kDa}, 47.71 \mathrm{kDa}, 40.80 \mathrm{kDa}, 31.41 \mathrm{kDa}$ and $17.79 \mathrm{kDa}$ were shown in analysis of $M$. laevigata variety leaves, while they were $344.47 \mathrm{kDa}, 77.33 \mathrm{kDa}, 67.02 \mathrm{kDa}$, $57.18 \mathrm{kDa}$ and $47.27 \mathrm{kDa}$ in analysis of $M$. alba var. Morittiana leaves. The dominant proteins bands in the leaves of the two mulberry varieties were 350, 67, 57 and $47 \mathrm{kDa}$, while the more abundant protein was 47 kDa. Protein bands molecular weight with 100, 87, 74, $40,31,17 \mathrm{kDa}$ were detected in M. laevigata leaves but were absent in $M$. alba var. Morittiana leaves profile.

\section{Electrophoretic patterns of haemolymph proteins}

The electrophoretic pattern of the $5^{\text {th }}$ instar haemolymph proteins (Table 1 and Figure 1) showed 12 and 15 polymorphic bands for larvae fed on $M$. laevigata and $M$. alba var. Morittiana leaves, respectively, with molecular weights range from 161.59 to $21.15 \mathrm{kDa}$.

Qualitative analysis of proteins exhibited obvious variations in the number and position of bands between the larvae reared on each of the two investigated mulberry varieties.

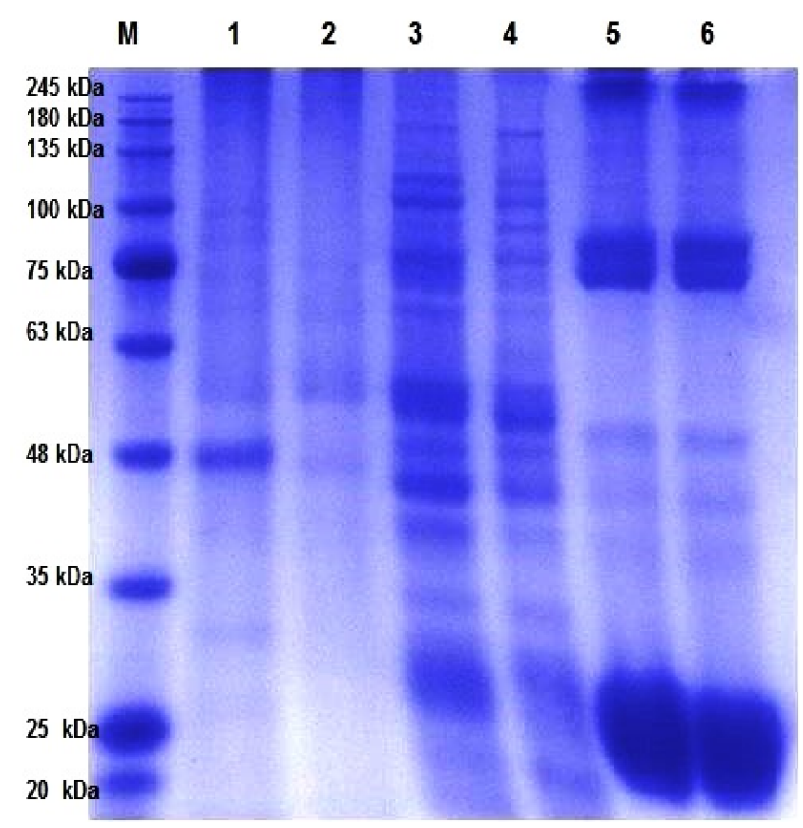

Figure (1): Protein pattern profiles of mulberry leaves, larvae haemolymph and silkgland of larvae fed on the two mulberry varieties.

$\mathrm{M}$ - Protein marker;

Lane 1 - M. laevigata mulberry leaves

Lane 2- M. alba var. Morittiana leaves

Lane 3- larvae haemolymph fed on M. laevigata

Lane 4- larvae haemolymph fed on M. alba var. Morittiana

Lane 5- Posterior silk gland in larvae fed on M. laevigata

Lane 6- Posterior silk gland in larvae fed on M. alba var. Morittiana. 
Table (1): Proteins molecular weights and raw volume percentage of mulberry leaves and larvae haemolymph and silkgland fed on the two mulberry varieties

\begin{tabular}{|c|c|c|c|c|c|c|c|c|c|c|c|c|c|}
\hline \multicolumn{2}{|c|}{ Protein marker } & \multicolumn{2}{|c|}{ Lane1 } & \multicolumn{2}{|c|}{ Lane2 } & \multicolumn{2}{|c|}{ Lane3 } & \multicolumn{2}{|c|}{ Lane4 } & \multicolumn{2}{|c|}{ Alne5 } & \multicolumn{2}{|c|}{ Lane6 } \\
\hline $\begin{array}{l}\text { Molecular } \\
\text { weight }\end{array}$ & $\begin{array}{c}\text { Abundance } \\
\%\end{array}$ & $\begin{array}{c}\text { Molecular } \\
\text { weight }\end{array}$ & $\begin{array}{c}\text { Abundance } \\
\%\end{array}$ & $\begin{array}{c}\text { Molecular } \\
\text { weight }\end{array}$ & $\begin{array}{c}\text { Abundance } \\
\%\end{array}$ & $\begin{array}{c}\text { Molecular } \\
\text { weight }\end{array}$ & $\begin{array}{c}\text { Abundance } \\
\%\end{array}$ & $\begin{array}{c}\text { Molecular } \\
\text { weight }\end{array}$ & $\begin{array}{c}\text { Abundance } \\
\%\end{array}$ & $\begin{array}{c}\text { Molecular } \\
\text { weight }\end{array}$ & $\begin{array}{c}\text { Abundance } \\
\%\end{array}$ & $\begin{array}{c}\text { Molecular } \\
\text { weight }\end{array}$ & $\begin{array}{c}\text { Abundance } \\
\%\end{array}$ \\
\hline 245.00 & 1.331 & 350.11 & 13.923 & 344.47 & 11.809 & 155.88 & 0.256 & 161.59 & 2.391 & 270.05 & 32.203 & 278.96 & 35.106 \\
\hline 180.00 & 2.762 & 100.00 & 3.299 & 77.33 & 1.384 & 115.40 & 2.925 & 114.62 & 2.015 & 134.08 & 0.226 & 135.00 & 0.006 \\
\hline 135.00 & 4.310 & 87.40 & 1.037 & 67.02 & 6.540 & 103.47 & 5.547 & 103.47 & 4.138 & 98.78 & 0.038 & 98.78 & 0.024 \\
\hline 100.00 & 5.636 & 74.16 & 2.198 & 57.18 & 5.217 & 77.33 & 10.023 & 91.23 & 1.748 & 80.72 & 32.265 & 84.25 & 12.787 \\
\hline 75.00 & 19.754 & 68.74 & 0.219 & 47.27 & 21.049 & 67.97 & 3.252 & 77.33 & 4.682 & 74.37 & 10.734 & 73.75 & 9.635 \\
\hline 63.00 & 7.447 & 57.36 & 5.174 & & & 55.42 & 11.375 & 72.92 & 0.183 & 50.30 & 9.815 & 50.62 & 6.279 \\
\hline 48.00 & 11.135 & 47.71 & 63.658 & & & 52.23 & 9.019 & 67.78 & 1.402 & 42.59 & 7.457 & 42.59 & 7.457 \\
\hline 35.00 & 19.481 & 40.80 & 0.041 & & & 49.06 & 2.775 & 55.42 & 6.090 & 38.14 & 4.027 & 37.90 & 3.334 \\
\hline 25.00 & 23.414 & 31.41 & 8.999 & & & 44.59 & 10.848 & 52.55 & 22.145 & 25.15 & 32.235 & 25.15 & 27.504 \\
\hline \multirow[t]{6}{*}{20.00} & 4.730 & 17.79 & 1.453 & & & 39.93 & 5.162 & 48.60 & 2.470 & & & & \\
\hline & & & & & & 33.69 & 4.365 & 43.78 & 6.362 & & & & \\
\hline & & & & & & 29.45 & 34.452 & 39.21 & 1.600 & & & & \\
\hline & & & & & & & & 32.63 & 3.736 & & & & \\
\hline & & & & & & & & 29.45 & 32.867 & & & & \\
\hline & & & & & & & & 21.15 & 3.857 & & & & \\
\hline
\end{tabular}


Protein profile of larvae fed on M. laevigata leaves was characterized by the presence of bands with a molecular weight of $155.88 \mathrm{kDa}, 115.40 \mathrm{kDa}, 103.47$ $\mathrm{kDa}, 77.33 \mathrm{kDa}, 67.97 \mathrm{kDa}, 55.42 \mathrm{kDa}, 52.23 \mathrm{kDa}$, $49.06 \mathrm{kDa}, 44.59 \mathrm{kDa}, 39.93 \mathrm{kDa}, 33.69 \mathrm{kDa}$ and 29.45 $\mathrm{kDa}$. While, protein bands observed in haemolymph of larvae fed on $M$. alba var. Morittiana leaves were $161.59 \mathrm{kDa}, 114.62 \mathrm{kDa}, 103.47 \mathrm{kDa}, 91.23 \mathrm{kDa}, 77.33$ $\mathrm{kDa}, 72.92 \mathrm{kDa}, 67.78 \mathrm{kDa}, 55.42 \mathrm{kDa}, 52.55 \mathrm{kDa}$, $48.60 \mathrm{kDa}, 43.78 \mathrm{kDa}, 39.21 \mathrm{kDa}, 32.63 \mathrm{kDa}, 29.45$ $\mathrm{kDa}$ and $21.15 \mathrm{kDa}$.

Most protein molecular weights were dominant in the two varieties except 91.23 and $72.92 \mathrm{kDa}$ which appeared in $M$. alba var. Morittiana leaves only. The protein band $30 \mathrm{kDa}$ was the most abundant band in larvae fed on the leaves of the two mulberry varieties.

\section{Electrophoretic patterns of silk gland proteins}

9 bands with molecular weight ranged between $350.11 \mathrm{kDa}$ to $25.15 \mathrm{kDa}$ were detected in electrophoretic profiles of the silk gland proteins (Table 1 and Figure 1). Silkgland Protein molecular weights were $270.05 \mathrm{kDa}, 134.08 \mathrm{kDa}, 98.78 \mathrm{kDa}, 80.72 \mathrm{kDa}$, $74.37 \mathrm{kDa}, 50.30 \mathrm{kDa}, 42.59 \mathrm{kDa}, 38.14 \mathrm{kDa}$ and 25.15 $\mathrm{kDa}$ in larvae fed on M. laevigata leaves. Similar bands were observed in silkgland of larvae fed on M. alba var. Morittiana leaves which were $278.96 \mathrm{kDa}, 135.00 \mathrm{kDa}$, $98.78 \mathrm{kDa}, 84.25 \mathrm{kDa}, 73.75 \mathrm{kDa}, 50.62 \mathrm{kDa}, 37.90$ $\mathrm{kDa}$ and $25.15 \mathrm{kDa}$. In all separated protein bands, the most abundant protein molecular weight was $25 \mathrm{kDa}$ in larvae fed on the leaves of the two tested mulberry varieties.

\section{DISCUSSION}

Obtained results clearly indicated differences in protein band numbers in grafted wild variety $M$. laevigata leaves, which were 10 protein bands while were five proteins bands in cultivated variety $M$. alba var. Morittiana leaves. Protein bands with molecular weights of $345 \mathrm{kDa}, 68.74 \mathrm{kDa}, 57.36 \mathrm{kDa}$ and $47 \mathrm{kDa}$ were common in the two mulberry varieties, but with different abundance. The abundant proteins in leaves were $47 \mathrm{KDa}$ which had a higher representation in $M$. laevigata in comparison to that in $M$. alba var. Morittiana leaves. Results are in agreement with that of Madhu Babu et al. (2014), who found that protein molecular weight of $48 \mathrm{kDa}$ and $55 \mathrm{KDa}$ were rather common in all the five examined mulberry varieties and the $44 \mathrm{kDa}$ protein was the major component of the leaf proteins.

Results are in context with Jyothi et al. (2016) who detected 10-12 protein bands in leaves of four cultivars and explained the relationship between mulberry leaves and silkworm protein patterns. They added that mulberry leaves protein bands may belong to sericin and fibroin family, the main components of silkgland and silk fibers.

The present qualitative analysis of proteins in larvae haemolymph are not typical but similar in 11 protein bands molecular weights with variations between the larvae reared on the leaves of the two investigated mulberry varieties. These proteins were involved in a variety of cellular functions, including metabolism, development, nutrient transport and reserve. Protein band of $30 \mathrm{kDa}$, was the abundant protein in haemolymph of larvae fed on the leaves of the two varieties. This finding has been confirmed by Zhang et al. (2014) who reported that storage proteins $30 \mathrm{KDa}$ constituted the most abundant groups of nutrient-storage proteins. Hyrsl and Simek (2005) have also reported that storage proteins, $30 \mathrm{kDa}$, were detected in protein patterns and were highly abundant at some developmental stages in haemolymph. These proteins are often called larval serum protein, larval specific serum proteins or larval haemolymph proteins. Comparative proteomics suggested that abundantly synthesized $30 \mathrm{~K}$ proteins in haemolymph of the fifth larval instar (the vigorous feeding stage) were taken up by and stored in fat body (storage tissue), to meet nutrient requirement of non-feeding stages, pupae, adults and eggs (Pakkianathan et al., 2012; Zhang et al., 2014).

The 9 bands with molecular masses of 278 to 25 $\mathrm{kDa}$ were detected in silkglands with similar patterns of larvae fed on leaves of the two mulberry varieties, while $25 \mathrm{kDa}$ was the more abundant protein in the silkgland of larvae fed on the two mulberry varieties leaves.

Present findings were supported by finding of Bhat and Manjunatha (2014) and Jyothi et al. (2016). They reported that the chief compositions of silk fiber are fibroin and sericin where fibroin composed of two proteins; light chain $(25 \mathrm{kDa})$ and heavy chains $(325$ $\mathrm{kDa})$. These two chains are linked together by di-sulfide bonds, whereas large number proteins observed in the SDS-PAGE gel could be cellular proteins, which might support the glandular cells for fibroin synthesis (Bhat and Manjunatha, 2014). Hence, this $25 \mathrm{kDa}$ protein band shall be fibroin L-chain as posterior silk gland involved in synthesis of only fibroin but not sericin.

The present study found that protein band numbers in the grafted $M$. laevigata variety leaves were more than that in $M$. alba var. Morittiana leaves. Hence, it is suggested that these bands may be related to enzymes or other components which make larvae gain the same weighs although it fed on leaves of mulberry variety that have a low proteins, nitrogen and free amino acids contents.

Although there are some differences in protein band numbers and abundance in the leaves of the two investigated mulberry varieties, the proteins pattern profile in haemolymph and silkgland of larvae fed on the leaves of both investigated mulberry varieties were closely similar which may mean that the grafted $M$. laevigata variety leaves can be used in silkworm Bombyx mori L. rearing system.

\section{REFERENCES}

Babu, T. M., R. Seenaiah, P. A. Basha and S. T. Naik (2014). Studies on the biochemical and bioassay different varieties of mulberry (Morus alba L.) leaves fed by silkworm in relation to silk production. International Journal of 
Biological and Pharmaceutical Research, 5(8): 664-667.

Bhat, M. A. and H. B. Manjunatha (2014). Electrophoretic separation and comparative analysis of silk gland proteins from Bombyx and Philosamia. International Journal of Bioassays, 3(8): 3214-3218.

Bovilla, V. R., M. K. Padwal, P. Siripurapu, B. Basu and A. Mamillapalli (2016). Developmental proteome dynamics of silk glands in the $5^{\text {th }}$ instar larval stage of Bombyx mori L (CSR2 $\times$ CSR4). Biochimicaet Biophysica Acta (BBA) Proteins and Proteomics, 1864(7): 860-868.

Dong, Z., P. Zhao, Y. Zhang, Q. Song, X. Zhang, P. Guo, D. Wang and Q. Xia (2016). Analysis of proteome dynamics inside the silk gland lumen of Bombyx mori. Scientific reports, 6: 21158.

El-Akkad, S. S., E. M. Hassan, I. M. Abdel-Nabi and A. H. AI (2008). The effect of mulberry varieties and nutritional additives on the protein patterns of the silkworm Bombyx mori. Egyptian Journal of Biology, 10: 11-19.

Hyrsl, P. and V. Simek (2005). An analysis of haemolymph protein profiles during the final instar, prepupa and pupa of the silkworm Bombyx mori (Lepidoptera, Bombycidae). Biologia, 60(2): 207-213.

Jyothi, M., M. Pratap, R. Seenaiah and Naik S. Thimma (2016). Biochemical Analysis and Protein Profile through SDS-page in Leaves of four (RC-1, RC-2, G-2 and G-4) Mulberry (Morus alba L.) Cultivars International Journal of Recent Scientific Research, 7(4): 10296-10300.

Jyothi, M. M., T. N. Pratap and S. Thimma (2014). Studies on biochemical constituents of different genotypes of Morus alba. Int. J. Pharm. Bio. Sci., 5(2): 835-840.

Li, J. Y., J. S. Li and B. X. Zhong (2012). Proteomic profiling of the haemolymph at the fifth instar of the silkworm Bombyx mori. Insect Science, 19(4): 441-454.

Li, J.Y., X. Chen, W. Fan, S. H. Hosseini Moghaddam, M. Chen, Z. H. Zhou, H. J. Yang, J. E. Chen and B. X. Zhong (2009). Proteomic and bioinformatic analysis on endocrine organs of domesticated silkworm, Bombyx mori L. for a comprehensive understanding of their roles and relations. Journal of proteome research, 8(6): 2620-2632.

Machii, K. and K. Katagiri (1991). Varietal differences in nutritive values of mulberry leaves for rearing silkworms. Japan Agricultural Research Quarterly, 5:23-27.
MadhuBabu, T., P. Chandra Obu Reddy, S. Thimma Naik (2014). Comparative studies of protein patterns in five mulberries (Morus Alba L.) cultivars through SDS-PAGE. Journal of Pharmacy and Chemistry, 8(4):30-33.

Manjula, M. and N. Vijaya Kumari (2015). Nutritional analysis of mulberry leaves. American International Journal of Research in Science, Technology, Engineering and Mathematics, 15(247): 332-334.

Pakkianathan, B. C., N. K. Singh, M. Krishnan and S. König (2012). A proteomic view on the developmental transfer of homologous $30 \mathrm{kDa}$ lipoproteins from peripheral fat body to perivisceral fat body via haemolymph in silkworm, Bombyx mori. BMC biochemistry, 13(1): 5-18.

Prieto-Abreu, M., M. Díaz-Solares, M. D. C. PérezHernández and D. Martín-Prieto (2016). Influence of three Morus alba L. varieties on the growth of Bombyx mori L. Pastos $\mathrm{y}$ Forrajes, 39(3): 132-137.

Rajitha, K. and G. Savithri (2013). Electrophoretic banding pattern of haemolymph proteins of silkworm Bombyx mori L. infected with fungal pathogen Beauveria bassiana (Bals.) Vuill. International Journal of Advanced Life Sciences, 6(5): 447-451

Vasudha, B. C., H. S. Aparna and H. B. Manjunatha (2006). Impact of heat shock on heat shock proteins expression, biological and commercial traits of Bombyx mori. Insect Science, 13: 243250.

Zannoon, A. H., E. M. Hassan, S. S. El-Akkad, I. M. Abdel-Nabiand S. M. Zalat (2008). Biological and technological effects of mulberry varieties and nutritional additives on silkworm Bombyx mori development. Egyptian Journal of Biology, 10(1): 1-10.

Zhang, Y., Z. Dong, D. Wang, Y. Wu, Q. Song, P. Gu, P. Zhao and Q. Xia (2014). Proteomics of larval hemolymph in Bombyx mori reveals various nutrient-storage and immunity-related proteins. Amino acids, 46(4): 1021-1031.

Zhou, Z. H., H. J. Yang, M. Chen, C. F. Lou, Y. Z. Zhang, K. P. Chen, Y. Wang, M. I. Yu, F. Yu, J. Li and B. X. Zhong (2008). Comparative proteomic analysis between the domesticated silkworm (Bombyx mori) reared on fresh mulberry leaves and on artificial diet. Journal of proteome research, 7(12): 5103-5111. 


\section{شرائح البروتين لاودة الحرير التوتية التي تتغذى على أوراق صنفي التوت البري و المنزرع كريمان محمود محمد

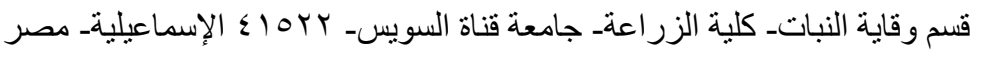

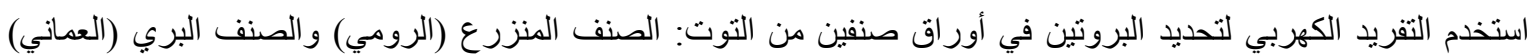

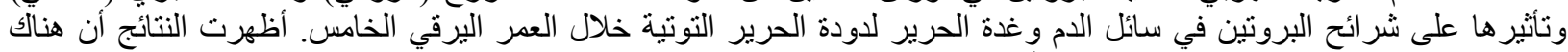

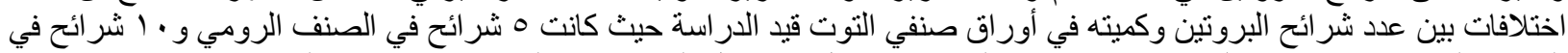

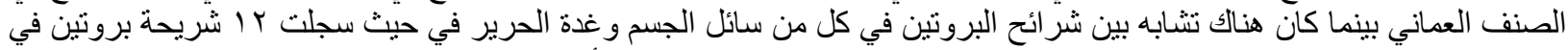

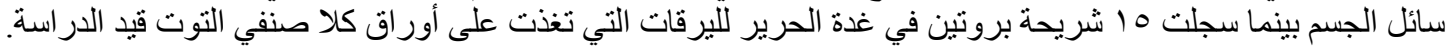

